\title{
A rapid assay method for cephalosporins
}

\author{
PAUL NOONE
}

From the Department of Bacteriology, Royal Free Hospital, London

SYNOPSIS A simple, rapid assay for cephalosporins is described. The method is based on the inhibition by cephalosporins of the fermentation of glucose or inositol by a strain of Providence resistant to aminoglycoside antibiotics.

The method gives answers which are as accurate as those obtained by standard agar diffusion techniques within four hours, and utilizes skills and resources readily available in most routine bacteriology departments. Results are not affected by gentamicin or kanamycin concurrently administered to the patient.

This method will be of value in helping to monitor cephalosporin therapy in patients with serious sepsis, especially those with impaired renal function, and may help in elucidating and preventing the problem of nephrotoxicity associated with cephalosporin administration.

In recent years it has become generally recognized that the use of potentially toxic antimicrobial agents in the treatment of serious sepsis needs to be monitored by the estimation of serum concentrations both to avoid toxicity and to ensure adequate dosage. With antibiotics such as aminoglycosides and cephalosporins which are excreted via the kidneys, the need for monitoring is increased in patients with impaired renal function or those undergoing dialysis. Moreover, if meaningful monitoring is to be achieved, it has become essential to employ rapid assay techniques.

Several rapid assay methods, designed principally for aminoglycosides, have been described, based on a four to six hour agar diffusion (Sabath, Casey, Ruch, Stumpf, and Finland, 1971; Reeves, 1972); on the inhibition of $\mathrm{pH}$ change by bacteria metatolizing lactose or urea (Faine and Knight, 1968; Noone, Pattison, and Samson, 1971; Noone, Pattison, and Slack, 1972); and on the adenylation of aminoglycosides with radioactive ATP by an R-factor-mediated enzyme (Smith, Van Otto, and Smith, 1972).

Rapid assay techniques for cephalosporins have not yet received as much attention. This situation may change as cephalosporins become increasingly used, usually in combination with gentamicin, as first-line drugs in the treatment of serious sepsis, such as Gram-negative septicaemia (Martin, Cuomo, Geraghty, Zager, and Mandes, 1969).

Received for publication 3 May 1973.
Standard doses of cephalosporins in such cases are in the range $6 \mathrm{~g}$ per 24 hours and more. Peak serum concentrations of 50 to $100 \mu \mathrm{g} / \mathrm{ml}$ and more are probably achieved. Nephrotoxicity attributable to cephalosporins, especially cephaloridine but also cephalothin, has been described (Kabins and Cohen, 1965; Benner, 1969; Foord, 1969; Pickering, Spooner, de Quesada, and Cade, 1970; Opitz, Herrmann, Herrath, and Schaefer, 1971) the incidence being increased by concurrently administered fruse- ? mide, the most widely used diuretic (Dodds and $\frac{5}{3}$ Foord, 1970). It has been suggested recently that nephrotoxicity is possibly associated with serum concentrations of cephaloridine in excess of $80 \mu \mathrm{g} / \mathrm{ml}$ (Winchester and Kennedy, 1972). This assumption 윽 has been questioned (McAllister, 1972) but much $\rightarrow$ more will be learned about such matters when cephalosporin therapy is more intensely monitored. N

Wardell and his coworkers have described the basis of a pH method of antibiotic assay based on $\mathrm{N}$ glucose fermentation by the Oxford $\mathrm{H}$ strain of $\omega$ Staph. aureus (Wardell, Yule, Ballard, and Forsyth, 1971). As described, this method has limitations both in terms of its sensitivity to concomitantly administered antibiotics, including aminoglycosides, and its failure to consider the problem of variations in the buffering capacity of individual human sera (Faine and Knight, 1968; Noone et al, 1971).

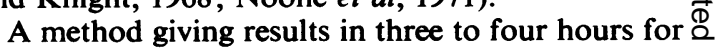
the assay of cephalosporins has been developed, based on the inhibition of the fermentation of either 8 glucose or inositol by a strain of Providence highly? 
resistant to the aminoglycosides, which overcomes the individual differences of particular patients' sera.

\section{Materials and Methods}

A strain of Providencia (group A) designated BS 750 , isolated from the leg ulcer of a geriatric patient, was chosen for the assay: (a) because of its resistance to the aminoglycosides including gentamicin; and (b) because of its ability to ferment glucose (and inositol) rapidly, compared with other coliforms tried, causing a fall in $\mathrm{pH}$ of from 1.0 to 1.5 units over a three-hour period. This fall in $\mathrm{pH}$ was inhibited by rising concentrations of cephalosporin, the rate of fall being greatest over the therapeutic range of cephalosporins (fig 1). The organism was identified

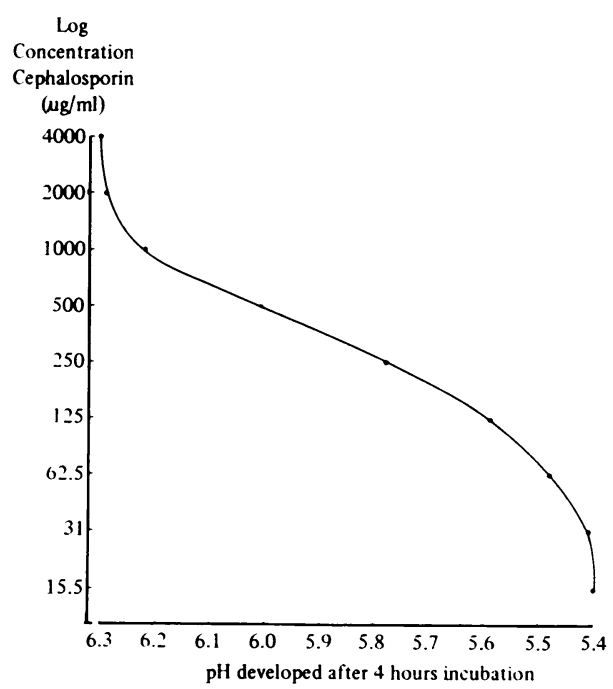

Fig 1 Inhibition of $\mathrm{pH}$ change by cephalosporin: $5 \mathrm{ml}$ of $4 \%$ glucose broth plus $0.4 \mathrm{ml}$ cephalosporin standards in pooled human serum inoculated with Providencia (BS 750) and incubated at $37^{\circ} \mathrm{C}$.

as Providencia spp according to the criteria of Cowan and Steel (1966) and was found by disc testing on lysed blood agar to be totally resistant (growth up to the margins of the disc) to gentamicin $(10 \mu \mathrm{g})$, kanamycin $(5 \mu \mathrm{g})$, streptomycin $(10 \mu \mathrm{g})$, and tetracycline $(10 \mu \mathrm{g})$. It is sensitive to ampicillin $(10 \mu \mathrm{g})$, carbenicillin $(100 \mu \mathrm{g})$, and cephaloridine $(5 \mu \mathrm{g})$. The minimum inhibitory concentrations of cephaloridine and cephalothin were $0.8 \mu \mathrm{g} / \mathrm{ml}$ and $1.6 \mu \mathrm{g} / \mathrm{ml}$ respectively, using as an inoculum $0.03 \mathrm{ml}$ of a 1/200 dilution of an overnight Todd Hewitt broth culture of BS $\mathbf{7 5 0}$.
A standard inoculum of from 0.03 to $0.3 \mathrm{ml}$ of an overnight Todd Hewitt broth culture of BS 750 exhibited maximum fermentation of $4 \%$ glucose and $3 \%$ inositol broth solutions, $5 \%$ and greater concentrations of glucose and $4 \%$ and greater concentrations of inositol, increasingly inhibited fermentation for a given inoculum. Concentrations below 4 and $3 \%$ respectively failed to stimulate maximum fermentation.

\section{MEDIUM}

Either $4 \%$ glucose broth (Oxoid CM67 with sterile $4 \%$ glucose added after autoclaving) or $3 \%$ inositol broth (made similarly) was used containing $0.4 \mathrm{mg}$ of Andrade's indicator per $100 \mathrm{ml}$. Both kinds of solution were buffered to $\mathrm{pH} 7 \cdot 1$ and stored in 100 $\mathrm{ml}$ aliquots at room temperature.

\section{STANDARDS}

Initially these were made fresh every day from cephaloridine (Glaxo) or cephalothin (Eli Lilly) in sterile phosphate buffer at pH6. In later assays by the ' $x / x / 2$ method' (see below), solutions of cephalosporins of $10 \mathrm{mg} / \mathrm{ml}$ or of $100 \mathrm{mg} / \mathrm{ml}$ were kept for periods of up to one week at $-20^{\circ} \mathrm{C}$. For the assay, standards were made from $1000 \mu \mathrm{g} / \mathrm{ml}$ to $62 \cdot 5 \mu \mathrm{g} / \mathrm{ml}$.

\section{METHOD}

Either $4 \%$ glucose or $3 \%$ inositol broth is dispensed aseptically in $5 \mathrm{ml}$ aliquots into each of $108 \mathrm{ml}$ plastic, disposable, screw-top tubes (Sterilin Ltd) All tubes in any given test are supplied with broth from the same bottle. The tubes are labelled ' $1000 x$ ', ' $500 x$ ', ' $250 x$ ', ' $125 x$ ', and ' $62 \cdot 5 x$ ' in one series and ' $100 x / 2$ ', ' $500 x / 2$ ', etc, in the second series.

Of freshly prepared cephalosporin standards, 0.4 $\mathrm{ml}$ is added to the appropriate tubes $-1000 \mu \mathrm{g} / \mathrm{ml}$ to the ' $1000 x$ ' and ' $1000 x / 2$ ' tubes and so on, then $0.2 \mathrm{ml}$ of antibiotic-free pooled human serum is added to each of the $x / 2$ tubes. Of patients' serum, $0.4 \mathrm{ml}$ is added to each of the $x$ tubes and $0.2 \mathrm{ml}$ of patients' serum to each of the $x / 2$ tubes, ie, $3.0 \mathrm{ml}$ of patients' serum in all.

Finally $0.2 \mathrm{ml}$ of a Todd-Hewitt broth culture of BS 750 , incubated from two to 24 hours at $37^{\circ} \mathrm{C}$, is added to each tube. An 18-hour culture is to be preferred and contains $5 \times 10^{5}$ organisms $/ \mathrm{ml}$ by the Miles and Misra surface counting method (1938). After the addition of the inoculum, each tube is inverted and shaken to mix thoroughly. The tubes are incubated in a water bath at $37^{\circ} \mathrm{C}$ for three to four hours until a red coloration develops strongly in the tubes with the least cephalosporin and before those with the highest concentration have followed suit.

The reaction is not halted, and the $\mathrm{pH}$ of each tube 
is read using a Pye Unicam $290 \mathrm{pH}$ meter, measuring accurately to 0.01 of a unit, and in the sequence ' $1000 x$ ', ' $1000 x / 2$ ', ' $500 x$ ', ' $500 x / 2$ ', etc.

Curves are plotted on semi-log paper of measured $\mathrm{pH}$ (horizontal axis) against the log of the nominal concentration of cephalosporin, ie, value of the standard. Two curves are obtained and the difference between them at any given $\mathrm{pH}$ is equal to half the cephalosporin concentration in the test serum (Noone et al, 1971). The cephalosporin concentration can be worked out as an average value from several readings (fig 2 ).

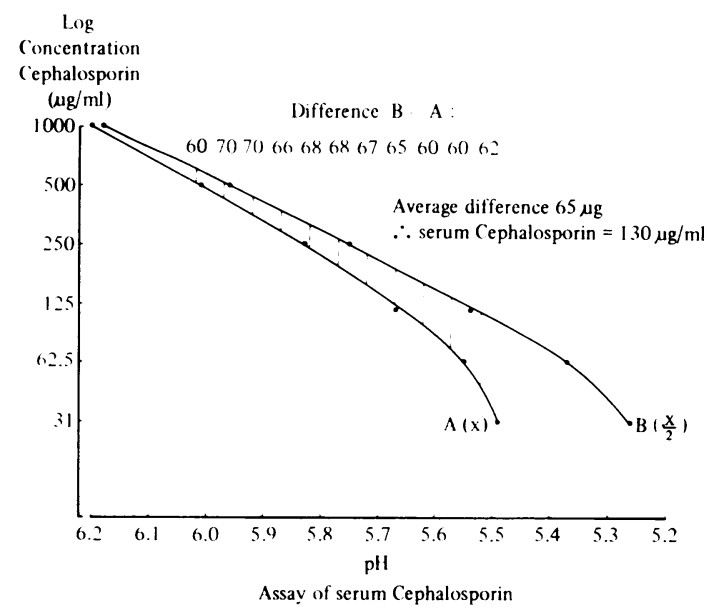

Fig 2 Curves plotted on semi-log paper of measured $p H$ against the log of the nominal concentration of cephalosporin (ie, value of the standard). The difference between the curves at any given $p H$ is equal to half the cephalosporin concentration in the test serum.

Initially 'straight' assays were performed, where the inhibition of $\mathrm{pH}$ change by $0.5 \mathrm{ml}$ of cephalosporin standards in pooled human serum, of $0.2 \mathrm{ml}$ of an overnight broth culture of BS 750 in $5 \mathrm{ml}$ of $4 \%$ glucose broth, was compared with $\mathrm{pH}$ inhibition produced by $0.5 \mathrm{ml}$ of test serum.

\section{PLATE ASSAY}

Conventional agar diffusion assays were performed using sensitivity test agar (Difco Bacto antibiotic medium 0270-01) seeded with the Oxford strain of Staph. aureus (NCTC 6571). Wells were cut and filled with cephalosporin standards in pooled human serum and dilutions of the test serum. Tests were performed in duplicate or triplicate. After 18 to 24 hours' incubation at $37^{\circ} \mathrm{C}$, diameters of zones of inhibition of growth of Oxford Staph. aureus were measured using calipers and plotted against the log concentration of standards. The serum concentrations could be read from the straight line obtained.

\section{Results}

The results are set out in the table where comparisons of plate assay and $\mathrm{pH}$ assay are made (1) on known amounts of cephalosporin added to antibiotic-free pooled human serum (unknown at time of test to experimenter) and (2) on specimens from patients. It will be seen that the 'straight' $\mathrm{pH}$ assay method is unreliable, giving accurate results in some instances but often yielding grossly wrong answers. However the ' $x, x / 2$ ' results are extremely good and consistent. This is exactly similar to the experience obtained with the urease assay method for aminoglycosides (Noone et al, 1971, 1972, and 1973a).

The addition of up to $200 \mu \mathrm{g} / \mathrm{ml}$ of gentamicin to the incubation mixtures failed to affect the fermentation of glucose by BS 750 .

\begin{tabular}{|c|c|c|c|}
\hline & $\begin{array}{l}\text { Plate Assay } \\
(\mu \mathrm{g} / \mathrm{m} /)\end{array}$ & $\begin{array}{l}\text { pH Method } \\
(\mu g \mathrm{ml})\end{array}$ & Known Concentrations \\
\hline $\begin{array}{l}\text { Straight Assay } \\
\text { Cephalothin }\end{array}$ & $\begin{array}{l}72 \\
36 \\
25 \\
52\end{array}$ & $\begin{array}{r}100 \\
39 \\
49 \\
72\end{array}$ & $\frac{-}{-}$ \\
\hline Cephaloridine & $\begin{array}{r}100 \\
70 \\
100 \\
41 \\
70\end{array}$ & $\begin{array}{r}25 \\
75 \\
128 \\
55 \\
120\end{array}$ & $\begin{array}{l}- \\
- \\
-\end{array}$ \\
\hline $\begin{array}{l}x-x / 2 \text { Method } \\
\text { Cephalothin }\end{array}$ & $\begin{array}{r}60 \\
100 \\
108 \\
600^{1}\end{array}$ & $\begin{array}{r}67 \\
96 \\
100 \\
160\end{array}$ & $\begin{array}{c}- \\
- \\
-\end{array}$ \\
\hline Cephaloridine & $\begin{array}{c}- \\
210 \\
100^{2} \\
180 \\
96^{2} \\
380 \\
110 \\
270 \\
360 \\
185 \\
160\end{array}$ & $\begin{array}{r}210 \\
106 \\
226 \\
124 \\
158 \\
84 \\
388 \\
78 \\
300 \\
324 \\
180 \\
168\end{array}$ & $\begin{array}{r}200 \\
100 \\
250 \\
125 \\
180 \\
90 \\
360 \\
100 \\
300 \\
350 \\
187 \\
175\end{array}$ \\
\hline
\end{tabular}

Table Straight assay and $x-x / 2$ method compared

${ }^{1}$ Patient also receiving benzylpenicillin

${ }^{2}$ Serum also contained $10 \mu \mathrm{g} \mathrm{ml}$ of gentamicin

\section{Discussion}

The main advantages of this $\mathrm{pH}$ assay method are its rapidity, simplicity, and reliance on materials and resources readily available in most routine bacteriology departments. In common with the urease $\mathrm{pH}$ 
assay method in our hands it is more reliable and at least as accurate as routine plate assay techniques. It is unaffected by concurrently administered aminoglycosides. The method employs $3 \mathrm{ml}$ of patients' serum-about $6 \mathrm{ml}$ of blood-not a large volume from an adult but probably too much if repeated assay is required from neonates. Reducing serum volumes leads to a loss of sensitivity of the method. The 'straight' assay matching $0.5 \mathrm{ml}$ of patients' serum with cephalosporin standards in pooled human serum leads relatively often to strikingly wrong results, attributable to variations in buffering capacity of individual specimens of serum. Work is in progress to overcome this problem.

Nevertheless the $x, x / 2$ method not only provides one method of solving this problem, it also has another clear advantage. By measuring a difference in a doubly diluted series of standards with an added aliquot of unknown serum, the $x, x / 2$ method does not need strictly accurate standards while still giving accurate answers (although standards must be prepared with as much care and accuracy as possible). Plate assay methods require very accurate standards or else an erroneous result is produced. With aminoglycosides, which are physiochemically stable, the maintenance of accurate standards is possible. Cephalosporins, however, deteriorate fairly rapidly in solution. This necessitates making up fresh standards each day from powdered antibiotic for assay purposes, which is time-consuming and leaves room for introducing error during the making up of standards. When employing the ' $x, x / 2$ ' method one is able to keep aliquots of cephalosporin at concentrations of $10 \mathrm{mg} / \mathrm{ml}$ or $100 \mathrm{mg} / \mathrm{ml}$ at $-20^{\circ} \mathrm{C}$ made up in phosphate buffer at $\mathrm{pH} 6$ and use a separate aliquot each day. In this way one vial of powdered cephalosporin can provide solutions lasting a week, saving time each day, and money too, as cephalosporins are expensive.

In this way the ' $x, x / 2$ ' method overcomes the problem of the lability of cephalosporin standards, the individual buffering capacities of particularserum, and, by being based on a method involving the use of five pairs of incubation mixtures each containing test serum, furnishes its own intrinsic multiple replication of the test, so obviating the need for performing the test more than once.

The cephalosporin assay is not as rapid as the urease method (Noone et al, 1973b). The splitting of urea by Proteus spp occurs more rapidly than the fermentation of glucose and other sugars by coliforms. In fact the urease activity of Proteus spp is so rapid that it is unaffected by the presence of cephalosporin, penicillin, and other antibiotics even when the organism is 'sensitive' to their action (Noone, 1972). The aminoglycosides and other antibiotics interfering with protein synthesis such as chloramphenicol and tetracycline exert their antibacterial effect much more rapidly and can thus inhibit urease production in sensitive organisms (Noone et al, 1973a; Rubenis, Kozij, and Jackson, 1973).

Because it depends on the antimicrobial activity of the antibiotic concerned, the $\mathrm{pH}$ assay method can be no more rapid than the antimicrobial effect allows. The cephalosporin assay takes up to four hours; the aminoglycoside assay by the urease method takes about one hour. The inhibitory effect of aminoglycoside is thus exerted within one hour illustrating the more rapidly effective antibacterial action of these antibiotics compared with cephalosporins. This is certainly matched by the good clinical results obtained with the proper use of gentamicin (Martin et al, 1969). Whatever cephalosporins are developed in the next few years, aminoglycosides will probably remain the drugs of choice for treating serious Gram-negative sepsis. Nevertheless cephalosporins have a useful antimicrobial role and this new assay method should help promote their more effective, safer usage.

\section{References}

Benner, E. J. (1969). Renal damage associated with prolonged administration of ampicillin, cephaloridine and cephalothin. Antimicrob. Agents and Chemother., 417-420.

Cowan, S. T., and Steel, K. J. (1965). Manual for the Identification of Medical Bacteria. Cambridge University Press, London.

Dodds, M. G., and Foord, R. D. (1970). Enhancement by potent diuretics of renal tubular necrosis induced by cephaloridine. Brit. J. Pharm., 40, 227-236.

Faine, S., and Knight, D. C. (1968). Rapid microbiological assay of antibiotic in blood and other body fluids. Lancet, 2, 375-378.

Foord, R. D. (1970). Cephaloridine and the kidney. In Progress in Antimicrobial and Anticancer Chemotherapy. (Proceedings of the 6th International Congress of Chemotherapy, Tokyo, 1969), Vol. 1, pp. 597-604. University Park Press, Baltimore.

Kabins, S. A., and Cohen, S. (1965). Cephaloridine therapy as related to renal function. Antimicrob. Agents and Chemother., 922-932.

McAllister, T. A. (1972). Absence of nephrotoxicity during cephaloridine therapy. Lancet, $2,710$.

Martin, C. M., Cuomo, A. J., Geraghty, M. J., Zager, J. R., and Mandes, T. C. (1969). Gram-negative rod bacteremia. J. infect. Dis., 119, 506-517.

Miles, A. A., and Misra, S. S. (1938). The estimation of the bactericidal power of the blood. J. Hyg. (Lond.), 38, 732-749.

Noone, P. (1972). Simple rapid method for the assay of antibiotics. In Conference Proceedings of the Pathological Society of Great Britain, January, London.

Noone, P., Pattison, J. R., and Samson, D. (1971). Simple rapid method for assay of aminoglycoside antibiotics. Lancet, 2, 16-19.

Noone, P., Pattison, J. R., and Slack, R. C. B. (1972). Rapid assay of gentamicin. Lancet, 2, 1194.

Noone, P., Pattison, J. R., and Slack, R. C. B. (1973a). Assay of gentamicin. Lancet. 1, 49-50.

Noone, P., Pattison, J. R., and Slack, R. C. B. (1973b). Simple rapid assay for measurement of antibiotic concentration in human serum. In Demonstration of Society for Applied Bacteriology, Autumn 1972 - to appear as a paper in Technical Series of the Society for Applied Bacteriology (Academic Press). In press.

Opitz, A., Herrmann, I., Herrath, D. von, and Schaefer, K. (1971). Akute Niereninsuffizienz nach Gentamycin-CephalosporinKombinationstherapie. Med. Welt., 22, 434-438. 


\section{Reports and Bulletins prepared by the Association of Clinical Biochemists}

The following reports and bulletins are published by the Association of Clinical Biochemists. They may be obtained from The Administrative Office, Association of Clinical Biochemists, 7 Warwick Court, Holborn, London, WC1R 5DP. The prices include postage, but air mail will be charged extra. Overseas readers should remit by British Postal or Money Order. If this is not possible the equivalent of 50p is the minimum amount that can be accepted.

SCIRNTIFIC REPORTS

3 Automatic Dispensing Pipettes. An assessment of 35 commercial instruments 1967 P. M. G. BROUGHTON, A. H. GOWENLOCK, G. M. WIDDOWSON, and K. A. AHLQUIST $80 \mathrm{p}(\$ 2)$

4 An Evaluation of five Commercial Flame Photometers suitable for the Simultaneous Determination of Sodium and Potassium March 1970 P. M. G. BROUGHTON and J. B. DAWSON 80p (\$2)

\section{SCIENTIFIC REVIEWS}

1 The Assessment of Thyroid Function March 1971 F. V. FLYNN and J. R. HOBBS 60p (\$1.50)

2 Renal Function Tests Suitable for Clinical Practice January 1972 F. L. MITCHELL, N. VEALL, and R. W. E. WATTS $60 \mathrm{p}(\$ 1.50)$

\section{TECHNCAL BULLETINS}

9 Determination of Urea by AutoAnalyzer November 1966 RUTH M. HASLAM 40p (\$1)

11 Determination of Serum Albumin by AutoAnalyzer using Bromocresol Green October 1967 B. E. NORTHAM and G. M. WIDDOWSON 40p (\$1)

13 An Assessment of the Technicon Type II Sampler Unit March 1968 B. C. GRAY and G. K. McGowAN 40p (\$1)

14 Atomic Absorption Spectroscopy. An outline of its principles and a guide to the selection of instruments May 1968 J. B. DAWSON and P. M. G. BROUGHTON 40p (\$1)

15 A Guide to Automatic Pipettes (2nd edition) June 1968 P. M. G. BROUGHTON 40p (\$1)
16 A Guide to Automation in Clinical Chemistry May 1969 P. M. G. BROUGHTON 60p (\$1.50)

17 Flame Photometers (2nd edition) 1969 P. WILDING $60 \mathrm{p}(\$ 1.50)$

18 Control Solutions for Clinical Biochemistry (4th edition) March 1970 P. M. G. BROUGHTON 60p (\$1.50)

19 Spectrophotometers. A comparative list of low-priced instruments readily available in Britain May 1970 C. E. WILDE and P. SEWELL 60p (\$1.50)

20 Quantities and Units in Clinical Biochemistry June 1970 P. M. G. BROUGHTON 60p (\$1.50) More than 30 copies in units of 10 at 20p

21 Filter Fluorimeters: A comparative list of 18 instruments September 1970 H. BRAUNSBERG and s. $s$. BROWN 60p (\$1.50)

22 Bilirubin standards and the Determination of Bilirubin by Manual and Technicon AutoAnalyzer Methods January 1971 BARBARA BILLING, RUTH HASLAM, and N. WALD $60 \mathrm{p}(\$ 1.50)$

23 Interchangeable Cells for Spectrophotometers and Fluorimeters September 1971 E. S. BROWN and A. H. GOWENLOCK 60p (\$1.50)

24 Simple Tests to Detect Poisons March 1972 B. W. MBADE et al. 60p (\$1.50)

25 Blood Gas Analysers May 1972 k. DIXON 60p (\$1.50)

26 Kits for Enzyme Activity Determination September 1972 S. B. ROSALKI and D. TARLOW 80p (\$2.00)

27 Assessment of Pumps Suitable for Incorporation into Existing Continuous Flow Analytical Systems November 1972 A. FLECK et al 60p (\$1.50) 